\title{
CONFLICTS BY WATER RESOURCE USE AND THE CASE OF ARARAQUARA-SP
}

\author{
Larissa Camerlengo Dias Gomes \\ Nemésio Neves Batista Salvador \\ Helena Carvalho de Lorenzo
}

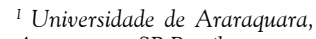
Araraquara, SP, Brasil

II Universidade de Araraquara, Araraquara, SP, Brasil

III Universidade de Araraquara, Araraquara, SP, Brasil

\begin{abstract}
This work presents hydric conflicts in Brazil, its causes and effects and the case of conflicts related to the supply and demand of groundwater in the municipality of Araraquara, Brazil. In this municipality, the situation is classified as critical by the Tietê-Jacaré Basin Committee, to which it belongs. The main factors that cause conflicts in Araraquara and the key actors involved were identified. The demands of groundwater users were determined and the users responsible for most of the total demand were identified by the ABC Method. These users, even in small number, are the main potential causers for the conflicts, involving public and private water supply. Public policies related to water resources and conflicts management are also discussed and measures for conflict attenuation are proposed. Such measures should be implemented by key actors and the main groundwater users involved.
\end{abstract}

Keywords: Water resources, groundwater, conflicts

São Paulo. Vol. 24, 2021

Original Article

DOI: http://dx.doi.org/10.1590/1809-4422asoc20190100r3vu2021L3AO 


\section{Introduction}

The history of humanity is marked by conflicts and a special highlight has been given to the increasing incidence of conflicts by the use and management of water resources. The literature identifies several driving factors for this type of conflict: scarcity, climate changes, unequal distribution of resources, population growth, water pollution and mismanagement of the available resources (LANNA, 2008; CAMPOS; FRACALANZA, 2010). Many conflicts by the use of water were originated in power disputes and currently cover regional and national disputes within the countries (VARGAS, 2007; CAMPOS; FRACALANZA, 2010).

To prevent or minimize conflicts, the governments of many countries have given several responses to the situation, such as implementing specific policies and changing the organization of the bureaucratic apparatus, either through the adoption of various management models or by means of administrative reforms (CORREIA et al., 2012; MOREIRA et al., 2012; DENICOLA et al., 2015). This theme has been gradually included in the research agendas in Brazil, highlighting studies that identify conflicts at local level in certain regions, and the respective adopted policies (CARNEIRO; ASSIS, 2013; AMORIM; RIBEIRO; BRAGA, 2016).

In the scope of this work, water conflicts are defined as tensions and/or frictions that may involve the action of various institutions and social actors, generally having two basic causes: pollution and degradation of water quality, which generate conflicts between polluters and users located downstream; and deficiency or scarcity of water supply to serve users, especially those downstream, who have access to a smaller amount of this resource. According to Di Mauro (2014) conflicts can occur due to poor water distribution, low water availability, unequal consumption and/or economic pressures, and may also be motivated, in the case of conflicts between countries, when the waters are in a cross-border territorial position.

Thus, water resource management policies are essential instruments for the regulation and mediation of conflicts (MACHADO, 2019), and according to Federal Law Nb. 9433/1997 of the National Water Resources Policy (PNRH ) (BRASIL, 1997), the Hydrographic Basin Committees (CBHs) are responsible to promote the debate of issues related to water resources, and to articulate the actions of entities, as well as to arbitrate conflicts involving such resources, in the first administrative instance.

The studies and analyses on the subject of water conflicts, presented and discussed on the following item, show that although this matter has been advanced in Brazil, either by the performance of $\mathrm{CBHs}$, or by results of academic research pointing out reasons and the nature of conflicts, there is still much to do to ensure the compliance with the fundamentals and objectives of the related PNRH in the face of these conflicts. In this sense, among the fundamentals of the PNRH, it should be highlighted that in situations of scarcity, the priority use of water resources is the human consumption and among the objectives of that policy, it should be ensured that the current and future generations must be assured of the necessary availability of water, in quality standards, appropriate to the respective uses, and the rational use of water resources with a view to sustainable 
development (BRASIL, 1997).

According to Lanna (2001), when the appropriation of water reaches a level close to that of its qualitative and quantitative availability, conflicts arise involving different entities and sectoral and local uses of a watershed. The author classifies conflicts according to the following factors: use destination - water is used for purposes other than those established by political decisions, which would be reserved for meeting social, environmental and economic needs; qualitative availability - related to the use of polluted or inappropriate water; quantitative availability - related to the depletion of quantitative water availability due to its intensive use.

The main purpose of this work is to provide research and identification of factors that can generate water conflicts in the municipality of Araraquara-SP, which, according to CETESB (2019a), has groundwater with good quality, but in a critical situation in relation to its quantity, according to the CBH-TJ (2018). This is due to overexploitation, when the relationship between the demand (flow) of groundwater granted and its supply (exploitable reserves) is higher than the limit of $50 \%$ in some municipalities of the Tietê-Jacaré Basin, including Araraquara (see Figure 1), what is conventionally classified as critical (CBH-TJ, 2018).

Villar (2016) states that overexploitation of groundwater lowers water levels, decreases aquifer storage capacity, compromises water quality by intruding contaminants present in shallow aquifers, causes subsidence, and reduces underground and surface water availability. Therefore, the possibility of imminent water risks and conflicts related to the quantitative availability of groundwater and the urgency of a more effective action, diagnosed from the socioeconomic and administrative specificities of each municipality, should be highlighted.

Figure 1 - Relationship between the demand for groundwater granted and the supply, as a percentage, in the UGRHI 13

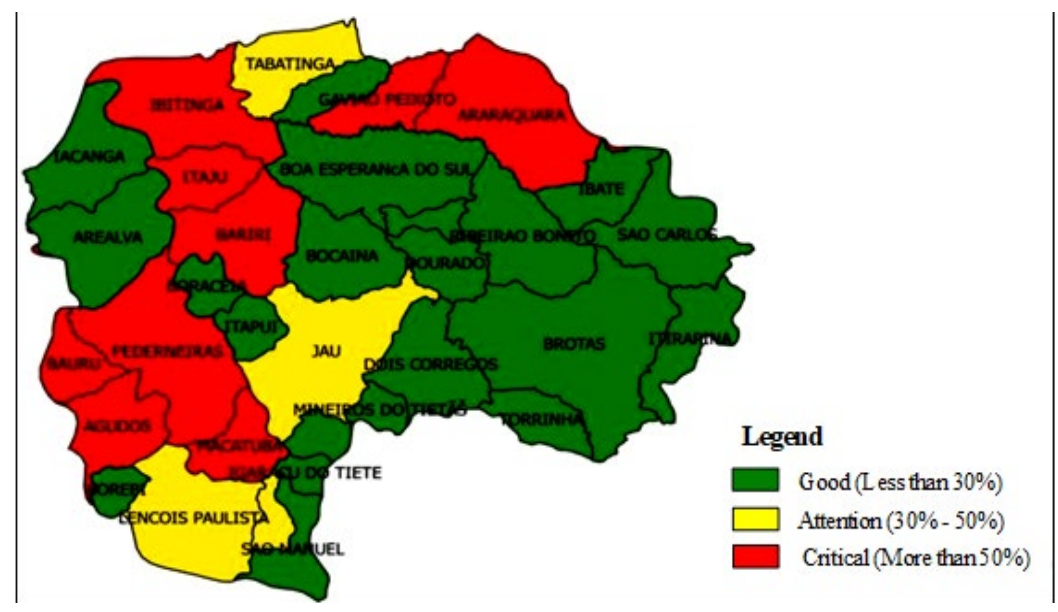

Source: CBH-TJ, 2018. 
It should be noted that according to the CBH-TJ (2018), there are no significant conflicts in relation to surface waters in the municipality of Araraquara. This region is cut by the Jacaré-Guaçu River, which is about $11 \mathrm{~km}$ distant from the city and presents both good quality water and sufficient availability (CBH-TJ, 2018; CETESB, 2019b), being collected today much less than the $50 \%$ allowed limit of the minimum reference flow (Q7.10) of the river (CBH-TJ, 2018). This allows the collection and additional use of its waters for various purposes, such as irrigation, industrial and public supply, which have already been considered in the Municipal Plan for Basic Sanitation of Araraquara (ARARAQUARA; WALM, 2014).

In the municipality of Araraquara, since the 1970s, the expansion of the sugarcane, orange and other food and beverage processing industries, as well as the mechanical metal industry (CAMPANHA; LORENZO, 2017), have been pressing and impacting the demand for water resources, including underground ones. According to IBGE (2019), in 2019 the municipality had an estimated population of 236,072 inhabitants and its growth rates have shown a declining trend, being $30.1 \%$ in the period between 1980-1991, and $13.1 \%$ in 2010-2019. In any case, these rates are positive and are responsible for the continuous increase of a significant portion of the water total demand for the purpose of public supply, which, according to Araraquara and WALM (2014), was supplied by about $45 \%$ by surface water and $55 \%$ by groundwater.

Thus, the research sought answers to the following questions: what are the causes and the main responsible actors for the potential conflicts of groundwater use in Araraquara? Are there adequate policies and strategies used by the municipality and boards responsible for the management of these waters, in relation to the limitation of use due to over-exploitation? What can or should be done?

\section{Conflicts by water use}

In the environmental area, the approach and studies on conflicts focus mainly on the theme of water resources, due to its essential character to human life and object delineated by different interests, especially those of political and economic nature (TUNDISI; MATSUMURA-TUNDISI, 2009; AMORIM; RIBEIRO; BRAGA, 2016).

There are several potential factors leading to water conflicts, such as: scarcity (CAMPOS; FRACALANZA, 2010; AMORIM; RIBEIRO; BRAGA, 2016); population growth (REBOUÇAS, 2003; PETRELLA, 2004); unequal distribution of resources (LANNA, 2008; TUNDISI; MATSUMURA-TUNDISI, 2009; BORBA; BAYER, 2015); climate change (LANNA, 2008); destruction of stratospheric ozone layer (HOMERDIXON, 1994); degradation and loss of agricultural soils and forests (HOMER-DIXON, 1994); and the depletion and pollution of freshwater sources (PETRELLA, 2004).

Problems of scarcity, management and conflicts over water resources have been frequently reported worldwide. Peek (2014) shows areas of possible conflicts in the world, and potential conflicts can be observed in South America, specifically in the Amazon and Paraná watersheds, including Brazil. SDC (2017) presents a map of conflicts in the 
world (Figure 2), similar to that illustrated by Peek (2014) and also covering Brazil. The Pacific Institute (2019) has developed a chronological list of 655 global water conflicts, from 3000 A.C. until 2019, in which four of them occur in Brazil.

Figure 2 - Map of potential conflicts by water resources in the world

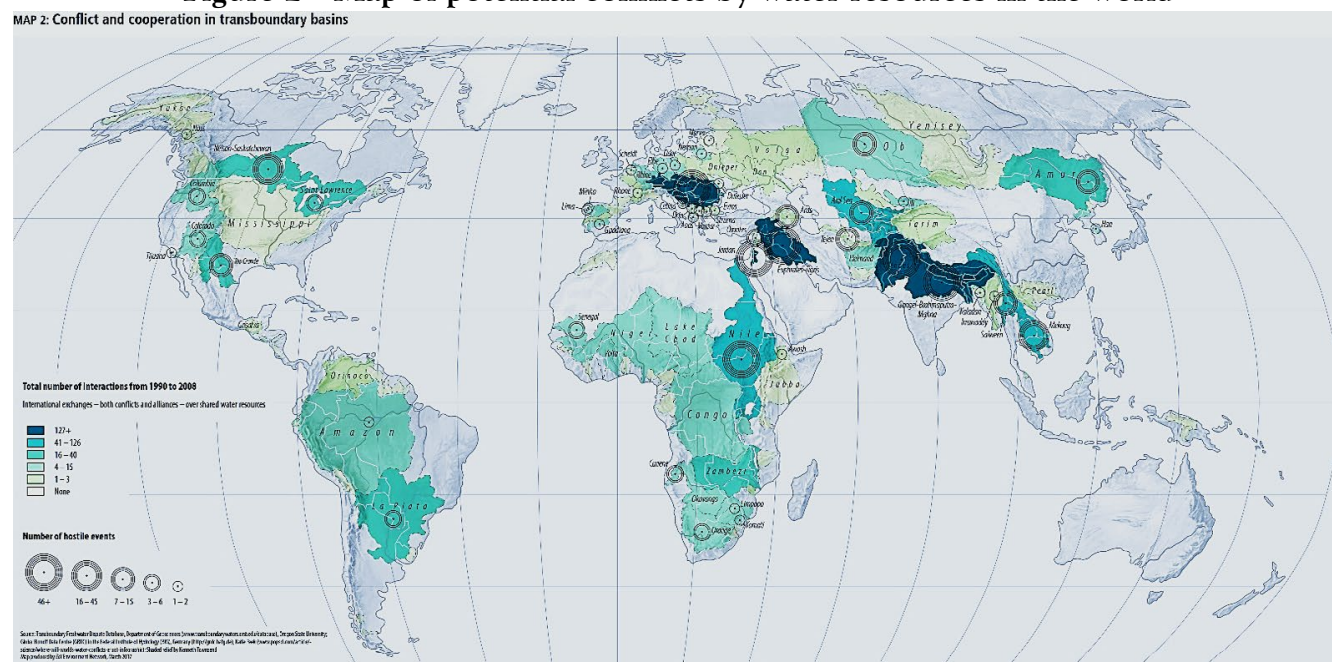

Source: SDC, 2017.

In several regions of Brazil, implicit and explicit conflicts have arisen, highlighting the difficulty of analyzing the implicit situations when the problem is restricted to small actors, or when it is difficult to identify and characterize them (GETIRANA, 2005). The country presents inequality in the geographical distribution of water resources, an accelerated increase in pollution, high rates of population growth and water scarcity, factors of high potential conflicts generation. These are directly resulting from the relationship between supply and demand and water use cycles, which determine the relationship or equation of water availability.

However, even in regions of great water availability and small demand in relative terms, conflicts may arise, as verified in the Amazon region, where hydroelectric dams have been causing problems with indigenous and riverside peoples, as well as problems of biodiversity/ fish reproduction, widely reported by the media, and subject of scientific works (FEARNSIDE, 2019; ROCK, 2019). Water supply is characterized not only by the available flow, but also by the quality of water, which, once degraded, generates scarcity. Water demand is characterized by consumptive uses, such as public, industrial and agricultural supply, livestock, aquaculture, as well as non-consumptive uses, such as navigation and fishing, and even the latter may also generate conflicts of political and/ or economic nature.

In the semiarid areas of northeastern Brazil, explicit conflicts are recurrent, mostly caused by water scarcity (BRITO, 2008; PINHEIRO; CAMPOS; STUDART, 2011; 
CORREIA et al., 2012). An example is the Piranhas-Açu River Basin, in the states of Paraíba and Rio Grande do Norte, where there were conflicts between water users in 2003, especially those in irrigation and shrimp farming. The increase in demand reflected in the number growth of grant applications for water allocations, being necessary the intervention of the Union, which implemented a cooperative and shared water management among those users (AMORIM; RIBEIRO; BRAGA, 2016).

Scarcity may also exist in regions that do not have scarce characteristics, but are settled in a scenario characterized by high demand and deficient supply, up to the point of providing inequalities and lack of water (HESPANHOL, 2002). This was the case of water crisis suffered by the State of São Paulo in 2015. A set of environmental problems related to climatic conditions and mismanagement led to the exhaustion of the Cantareira System, the main source of the São Paulo metropolitan area. There was interruption of water supply, generating negative externalities in aquatic ecosystems, conflicts between public authorities and population and the slowdown of the economy, due to the restriction on water consumption by the industrial and commercial sectors (JACOBI; CIBIM; LEÃO, 2015).

In the same period of time, the impact of water scarcity caused several conflicts also in the State of Rio de Janeiro. In January 2015, the State Government instituted the Water Security Office, whose main objective was to define and monitor the implementation of emergency and short-term solutions necessary to deal with the water crisis (COSTA et al., 2015).

According to Canuto; Luz; Andrade (2015), studies by the Pastoral Land Commission (CPT) reported 135 conflicts from water use in Brazil, in 2015, mostly in rural areas. These conflicts generated concern about food security caused by a decrease in agricultural productivity, affected by soil degradation and water scarcity. Also according to the CPT (2019), there were 197 and 276 water conflicts in the country in 2017 and 2018, respectively.

There is a great need for effective management in the use of water resources, being one of its instruments the grant for water allocation. Its use reflects in the regulation between the supply and demand of these resources, since it is possible for the granting body to restrict the amount of water to be captured. However, even this instrument did not avoid conflicts between the various uses in the Rio do Sono Basin, in Minas Gerais, where disputes were identified due to the concession of grants in higher number than feasible/ permissible (MOREIRA et al., 2012).

In summary, it may be observed in the literature on the subject that strong contradictions between the regulation and grant concessions above the permitted level do exist, being the heart of conflicts that may occur in the future in Brazil. The lack of regulation, use planning and flexibility in grant concession, in view of the demands of economic and population growth, point out to a serious potential for conflicts, mainly in locations with high population growth and productive segments with high water demand.

Specifically in this work, the potential for conflicts due to the use of groundwater in the region, evidenced in the report of the Basin Committee (CBH-TJ, 2018), indicates 
its priority in relation to the demand for surface water. The study of the municipality of Araraquara constitutes a locus favorable to the construction of hypotheses as subsidies for policies to improve groundwater use conditions, in consideration of its economic, social and environmental development.

\section{Methodology}

This work was developed through an exploratory and quali-quantitative research, involving bibliographic, documental and field research, by gathering information and secondary and primary data. A case study (YIN, 2015) was also conducted, which proved to be an appropriate strategy, as a tool to explain both the trends suggested in the initial studies on the potential for the emergence of conflicts for groundwater in the municipality of Araraquara, and its determining factors. This municipality was chosen for its importance in the Tietê-Jacaré Basin and, above all, for its critical situation in relation to the exploitation of groundwater (CBH-TJ, 2018).

The documental research consisted of information and data collected in the City Hall, in the Autonomous Department of Water and Sewage of Araraquara (DAAE) and on the websites of the CBH-TJ, the Department of Water and Electric the Energy of the State of São Paulo (DAEE), the National Water Agency (ANA), the Environmental Company of the State of São Paulo (CETESB) and the Brazilian Institute of Geography and Statistics (IBGE). Based on these information and data, the main factors that enhance conflicts in Araraquara were identified and analyzed. The potential of these factors was classified based on the data collected through the methods of documental research and literature review.

The results were organized after considering the main risk factors of conflicts found in the literature: unequal distribution of water resources, climate change, population growth, pollution, mismanagement, and three classes of potentiality or propensity to conflicts (low, medium and high) proposed by the present authors in order to systematize and hierarchize these results. The factors and their respective potentialities were organized in the form of a flowchart (Figure 3 presented ahead).

The field research was carried out at the DAEE Technical Support Office in Araraquara, the body responsible for the granting of water collection in the State of São Paulo, by accessing its database, in which all the concessions granted by the agency for the capture of groundwater, as well as the registration of the respective users and their data, are documented.

Initially, users were screened, disregarding the non-active actors and considering only the active water grants until December 2016, which resulted in a total of 1,411 users with current grants, a universe that constituted the object of this stage of the study. Next, the flow granted to each user was determined, based on the operational flow $(\mathrm{m} 3 / \mathrm{h})$ contained in the records of the pumping tests for each well, which were transformed into instantaneous flow $(1 / s)$.

It should be noted that the flow granted is an exploration right for each user, thus 
constituting a potential consumption. However, real or effective consumption may be lower than potential consumption, since not all users utilize the total flow granted.

After determining all the flows, users of very low flow, lower than $0.2 \mathrm{l} / \mathrm{s}$, were discarded, resulting in a set of 687 users, whose water demands were systematized and classified by the ABC Method (PEINADO; GRAEML, 2007) in order to identify those responsible for the great or greater demands.

The ABC Method has been employed by several authors and institutions in environmental management and pollution control (SALVADOR; FIGUEIREDO; FIGUEIREDO; MACHADO, 2008; SÃO PAULO, 2013; ABRÃO JUNIOR; AGUIAR, 2015). The Method classifies certain occurrences, allowing them to be prioritized relatively and, according to Peinado and Graeml (2007), makes it possible to identify the relative importance of the variables of a problem, allowing the verification of how much each variable represents the general problem, in percentage terms.

In the present case, the application of the referred method consisted in the percentage classification of the variable demand of water (granted flows) and the elaboration of the Pareto Diagram or ABC Curve (PEINADO; GRAEML, 2007). In this way, the 687 users were listed in a table by the highest flows in decreasing order and by the accumulated flows and respective percentages in relation to the total flow, being these percentages plotted in the ABC Curve (Figure 4), according to the number of users.

\section{Potentiating conflict factors of groundwater use in Araraquara}

As mentioned, conflicts over water resources are enhanced by various factors, including geographic characteristics and unequal distribution or supply of resources, climate change, population and economic growth, water scarcity, pollution, poor planning and resources mismanagement (PETRELLA, 2004; LANNA, 2008; FIELDS; FRACALANZA, 2010; AMORIM; RIBEIRO; BRAGA, 2016; MEKONNEN, MONESE; HOEKSTRA, 2016). These factors were analyzed and evidenced their potential for generating conflicts, explicit or veiled, for the municipality of Araraquara.

The flowchart in Figure 3 shows the relationship between the factors that influence groundwater use conflicts and its hatching potential. 
Figure 3 - Factors and potentialities of water conflicts related to groundwater in Araraquara: classification proposal

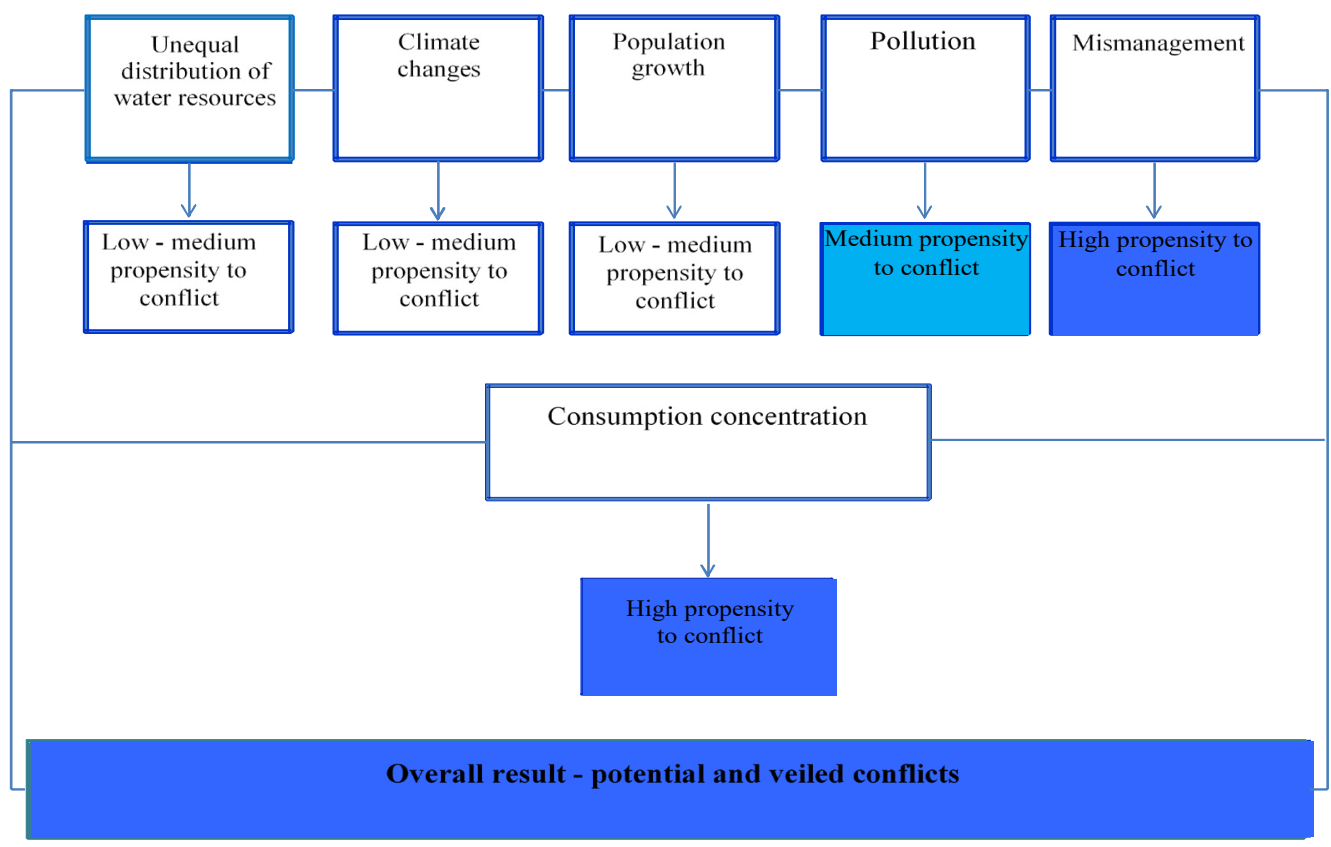

Source: Authors, 2018.

In order to analyze the potentiating factors of water conflicts related to groundwater (Figure 3), it was necessary to elaborate criteria for the organization of data research and evaluation of the conflict level. The literature on the subject and the observation of reality done by the researchers, suggested the criteria explained as follows.

For the first factor indicated in Figure 3, unequal geographical distribution of water resources, the criteria emerged from the analyses of Homer-Dixxon (1994), Petrella (2004) and Mekonnen \& Hoekstra (2016). These authors point out that conflicts occur in situations in which natural reserves are deficient and distribution of resources are unequal, as occurring in semi-arid and arid regions. Such fact is not strongly present in the studied context, as Araraquara benefits from several springs and reserves still relatively satisfactory, with the exception of groundwater (CBH-TJ, 2018). However, the municipality, in its Development Master Plan (ARARAQUARA, 2014), allows residential spaces to be allocated in water sources areas, which impairs the recharge of the aquifer and, consequently, the water supply. Because of this panorama, the unequal distribution of resources was considered a potentiality with a low to medium level, for the outbreak of conflicts.

Regarding the climate change factor, Lanna (2008) mentions that hydrological systems have been affected by climate changes in various parts of the world and recommends each country to consider this aspect in the formulation of its water resources 
policies. In the development of this work, it was verified that local and regional planners practically do not take climate changes under consideration, given the lack of information in guide documents, such as water resource situation reports and management plans. Climate changes tend to decrease the recharge capacity of the water system (CHAVES; ALBUQUERQUE; MATTOS, 2010); however, the uncertainty surrounding this effect in the Region of Araraquara led this factor to be classified as low to medium potential.

As for population growth, the impact of this factor on the demand for groundwater resources is mentioned by Rebouças (2003), being supported by the result of the application of the ABC Method, to be presented ahead, which positions the DAAE as being notably the biggest groundwater user by its public supply activity. However, because the population growth rate has been decreasing, as mentioned earlier (IBGE, 2019), while the participation of industrial production of food products, high groundwater users, has been increasing (CAMPANHA; DE LORENZO, 2017), putting even more pressure on its demand, the population growth factor was considered as low to medium risk for outbreak of conflicts.

Groundwater quality can be influenced by anthropogenic activity, which is the source of punctual polluting loads from domestic or industrial origin (CETESB, 2019a). Regarding the pollution factor, it is evident that Araraquara, despite having collection and treatment of approximately $100 \%$ of the domestic sewage generated, presents a treatment efficiency considered low, for example, less than $80 \%$ in terms of removal of Biochemical Oxygen Demand (BOD) (CBH-TJ, 2018). It is also observed the existence of pollution in some stretches of its rivers, including springs, due to urban occupation (ARARAQUARA; WALM, 2014). It is concluded, therefore, that pollution is a conflictpotentiating variable in the municipality, which is in a relatively worrying scenario, that demands interventions. Surface water pollution ends up putting pressure on the demand for better quality groundwater. So, for the pollution factor, the propensity to conflicts outbreak was classified as medium.

Poor management of water resources is another important potential factor that generates conflicts. It is a consequence of several aspects, such as: lack of integration of the involved institutions, with overlap of activities and concentration of decisions and actions; ignorance of potential conflicts; lack of systematization and crossing of information; fragile/ inadequate criteria in water granting; absence of monitoring and inspection; society's low participation both in the public policies formulation and implementation and in basin committees (PETRELLA, 2004; VARGAS, 2007; LANNA, 2008; CAMPOS; FRACALANZA, 2010; MOREIRA et al., 2012; JACOBI; CIBIM; LEÃO, 2015). These former aspects reinforce the conclusions of Malheiros; Prota; Rincón (2013), as mismanagement increases water vulnerability and intensifies the problems of water scarcity and conflicts.

A serious management problem in Araraquara, which reflects negatively on the demand for water resources, is the loss in the public water supply system. According to CBH-TJ (2018), between 2011 and 2013, the city had a loss rate above 40\%, considered bad and compromising for the management system. In 2014 and 2015, there was a small 
improvement, with the index just below $40 \%$, considered as a regular level. It should also be emphasized the existence of clandestine wells (CETESB, 2019a), without any grant nor adequate control, which occurs in many cities of the country. Due to all these aspects, the propensity to conflict of the management factor was classified as high.

The last factor analyzed was the consumption concentration, detailed and discussed ahead, in the next section, with the application of the ABC Method to the demands of groundwater users in the municipality of Araraquara. The great demand for water resources concentrated in few users can constitute an important driving component of water stress, which occurs in Araraquara in relation to groundwater - see Figure 1 (CBH-TJ, 2018), thus positioning this factor as being of high potentiality to conflicts.

It is emphasized that not all conflict-potentiating factors have the same impacts in a locality. Each region has different characteristics and these peculiarities are closely related to these factors, which are not necessarily all present or cause the same effect.

According to ANA (2015), the deepening of the knowledge of critical watersheds regarding water resources can help subsidize the direction of management actions to sites that present potential or imminent conflict and need immediate attention. One realizes that there are some uses which compromise others, but there is not necessarily explicit conflict between them because, in some cases, potential conflicts may not evolve to real conflicts and actions should be aimed at preventing this evolution.

\section{Main responsible by the potential conflicts in the groundwater use}

The potential conflicts due to the use of groundwater in Araraquara could be identified mainly based on three aspects: great users, main conflict-enhancing factors and the main actors involved.

Table 1 presents, in its first part, a synthesis of the classification by the ABC Method of 687 users in total, and in the second part, the flow or demand of groundwater of 16 users belonging to Class $\mathrm{A}$.

It is observed in the first part of the table that Class A users are responsible for a large majority of demand and potentially represent the main factor of scarcity and conflicts. The first (or greater) 16 users were classified, with flows higher than $70 \mathrm{l} / \mathrm{s}$, representing about $80.4 \%$ of the accumulated water demand and only $2.3 \%$ approximately the total number of users. Those users are considered as high to very high priority for the purpose of sustainable use of groundwater, since they account for much of total water demand and, therefore, management efforts should be concentrated on them as a priority.

The 137 following users, with flows of up to 70 l/s, were classified as Class B and account for about $13.2 \%$ of the total water demand; and $19.9 \%$ of the number of users were considered as low to medium priority. The other 534 users, with small demands, account for only about $6.4 \%$ of the all demand and represent approximately $77.7 \%$ of the total users, being classified as Class $\mathrm{C}$ and considered as non-priority or low priority for management purposes.

Due to their high number (671), because they have small flows and are predomi- 
nantly low priority or non-priority, class B and C users were not listed in Table 1; however, they are represented in the ABC curve presented ahead (Figure 4).

Table 1 - Synthesis of the classification by the ABC Method and groundwater demands in Araraquara by the Class A users

\begin{tabular}{|c|c|c|c|c|c|c|}
\hline Class & User number & \multicolumn{2}{|c|}{ User percentage $(\%)$} & $\begin{array}{c}\text { Demand/water } \\
\text { flow }(1 / s)\end{array}$ & \multicolumn{2}{|c|}{ Water demand percentage (\%) } \\
\hline A & 16 & \multicolumn{2}{|c|}{2.33} & $6,335.7$ & \multicolumn{2}{|c|}{80.44} \\
\hline B & 137 & \multicolumn{2}{|c|}{19.94} & $1,035.9$ & \multicolumn{2}{|c|}{13.15} \\
\hline $\mathrm{C}$ & 534 & \multicolumn{2}{|c|}{77.73} & 505.1 & \multicolumn{2}{|l|}{6.41} \\
\hline Total & 687 & \multicolumn{2}{|c|}{100.00} & $7,876.7$ & \multicolumn{2}{|c|}{100.00} \\
\hline $\begin{array}{c}\text { Class A } \\
\text { user }\end{array}$ & Activity & $\begin{array}{c}\text { Flow } \\
(1 / s)\end{array}$ & $\begin{array}{c}\% \text { of total } \\
\text { flow* }\end{array}$ & $\begin{array}{c}\text { Accumulated flow } \\
(1 / s)\end{array}$ & $\begin{array}{c}\% \text { of accumulated } \\
\text { flow } *\end{array}$ & $\begin{array}{l}\% \text { of the } \\
\text { total users* }\end{array}$ \\
\hline 1 & Public water supply & $2,576.7$ & 32.71 & $2,576.7$ & 32.71 & 0.15 \\
\hline 2 & Juice industry & 687.7 & 8.73 & $3,264.4$ & 41.44 & 0.29 \\
\hline 3 & Beer industry & 582.2 & 7.39 & $3,846.6$ & 48.83 & 0.44 \\
\hline 4 & Textile industry & 504.5 & 6.40 & $4,351.0$ & 55.24 & 0.58 \\
\hline 5 & Rural - sugar cane & 472.2 & 6.00 & $4,823.3$ & 61.23 & 0.73 \\
\hline 6 & Alcohol industry & 298.7 & 3.79 & $5,122.0$ & 65.02 & 0.87 \\
\hline 7 & Chemical industry & 178.2 & 2.26 & $5,300.2$ & 67.29 & 1.02 \\
\hline 8 & Alcohol industry & 161.0 & 2.04 & $5,461.2$ & 69.33 & 1.16 \\
\hline 9 & Rural - orange & 154.7 & 1.96 & $5,615.9$ & 71.29 & 1.31 \\
\hline 10 & Energy service - sanitary & 140.7 & 1.79 & $5,756.6$ & 73.08 & 1.46 \\
\hline 11 & Rural - sugar cane & 116.9 & 1.48 & $5,873.5$ & 74.56 & 1.60 \\
\hline 12 & Rural - livestock & 111.1 & 1.41 & $5,984.6$ & 75.97 & 1.75 \\
\hline 13 & Food industry & 100.2 & 1.27 & $6,084.8$ & 77.25 & 1.89 \\
\hline 14 & Leisure club & 92.8 & 1.18 & $6,177.6$ & 78.43 & 2.04 \\
\hline 15 & Block industry & 88.0 & 1.12 & $6,265.6$ & 79.54 & 2.18 \\
\hline 16 & Hotel service & 70.2 & 0.89 & $6,335.7$ & 80.44 & 2.33 \\
\hline & Total & $6,335.7$ & 80.44 & $6,335.7$ & 80.44 & 2.33 \\
\hline
\end{tabular}

* Refers to the total of 687 users.

Source: Authors, 2018.

As it can be seen in the second part of the table, there is a diversity of use in class A, with users of industry, agriculture, commerce and services, electricity, leisure and public supply. The public supply by the DAAE is the largest responsible for the granted demand, totaling almost one third of it (32.7\%), which shows its great pressure on the underground water reserves of the municipality. In second place is the industrial segment (eight industries), representing 33.0\%, followed by the rural sector (four activities) with about $10.9 \%$, and by the other sectors (three activities) - electricity, leisure and services, which together represent approximately 3.9\% of demand. 
In the case of water scarcity and conflicts between users, solutions should be sought to resolve them, but, in the presence of an impasse, the use for human consumption prevails, as it is a priority, according to the National Water Resources Policy (BRASIL, 1997).

The industrial sector in Araraquara brings together large water-user industries, such as juice, beer, textile and alcohol, which compete for this resource among themselves and with public supply. In addition, the juice and beer industries demand very high quality water in their manufacturing processes, then using exclusively groundwater. Therefore, it is virtually unfeasible for them to be supplied solely by the DAAE and the choice of its industrial plants location certainly took into account the presence of good quality groundwater in the region, more than the availability of DAAE services, which normally provides a mixture of surface and groundwater, drinkable, but of lower quality than pure groundwater.

Figure 4 shows the elaborated ABC Curve, with the percentage distribution of the accumulated demands of 687 users, belonging to Classes A, B and C. Note the wide predominance of the 16 Class A users, shown in Table 1 , which, even in a small number represent more than $80 \%$ of the total demand for groundwater granted and constitute themselves as potential conflict generators, thus demanding special attention/ priority.

Figure 4 - $\mathrm{ABC}$ curve of groundwater demands in Araraquara

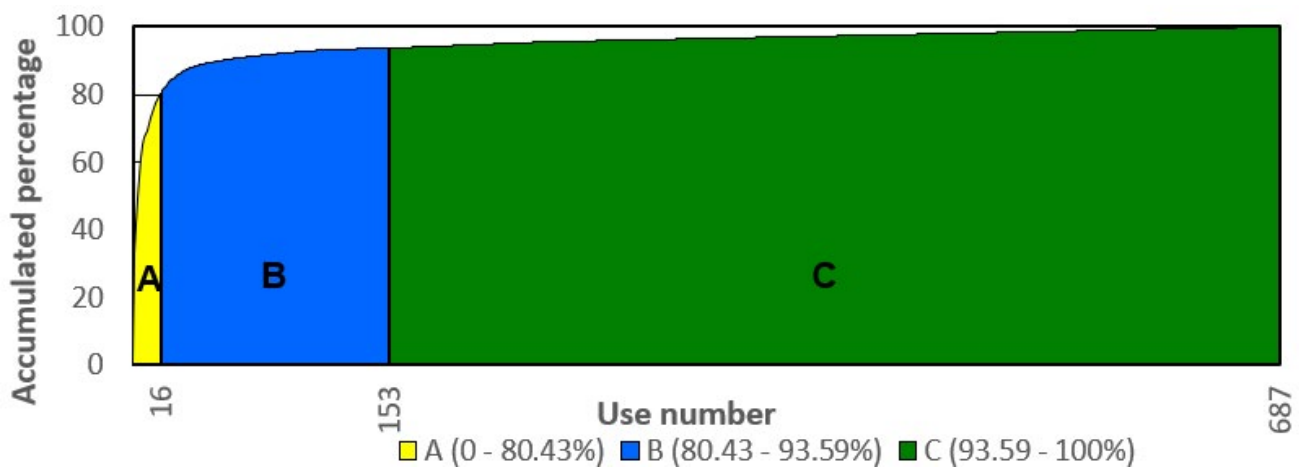

Source: Authors, 2018.

\section{Final considerations}

This research confirmed the potential for strong conflicts in the use of underground water resources in the municipality of Araraquara. These may, in the long term, manifest themselves in a severe, more intense way, considering that there is a great demand for concentrated water in a few users. The potential conflict between public (DAAE) and private use (industry, irrigation etc.), as well as between private users by the demand for better quality underground water, to the detriment of superficial water, is emphasized.

Contributing to this situation, as seen previously in this work, the municipality has a still significant population growth, high water loss in the distribution system, pollution of surface water sources and fragility of public policies targeting these problems. This 
scenario reinforces the results of this study, which indicate that these environmental, socioeconomic, political and institutional factors are potentializers or propellers of conflicts, given the situation of stress in the supply/ demand of groundwater, which has long been recognized by the $\mathrm{CBH}-\mathrm{TJ}$ itself, in its annual reports on the status of water resources at UGRHI 13. The reports suggest specific management of these resources in the case of critical municipalities, but this has not yet been implemented (CBH-TJ, 2018).

With no intention to generalize the results to the other municipalities of the TietêJacaré Basin, a policy of differentiated charge for the use of water resources by large users of groundwater in municipalities in critical situation, such as Araraquara, (see Figure 1) is suggested, aiming at the rational and sustainable use of water. The CBH-TJ should also stimulate projects of the State Water Resources Fund (FEHIDRO) and other programs that contemplate the conservation of water resources and the protection of aquifer recharge areas, especially those that supply critical municipalities.

With respect to DAEE, the first thing that should be done is to provide it with a legal/ normative apparatus with better-defined and stricter criteria for granting related to groundwater exploitation in municipalities with critical situation, mainly targeting large users, such as those in the municipality of Araraquara, classified in Class A. The policy of granting for irrigation should be reconsidered, including guiding and stimulating surface water collection. The DAEE should also take more effective actions to curb illegal or irregular wells, with priority in municipalities that are critical for groundwater.

On the other hand, CETESB should also implement or intensify programs to monitor groundwater quality, especially for the aquifers that supply critical municipalities, as well as exercise greater supervision over their sources of pollution.

At the municipal level, the DAAE should intensify the control of losses in the water supply system, since in Araraquara the underground source is mainly used. The DAAE could also promote sanitary and environmental education programs, both to its users and the general population, aiming at the rational use and conservation of water resources.

Bearing in mind that the management of water resources has repercussions on land use, and vice versa (LANNA, 2001), the City Hall, in turn, has a fundamental preventive role through its urban policies, by means of urban planning and other instruments for regulating land use and occupation, with emphasis on the Municipal Development Master Plan and other legal, regulatory and administrative attitudes and guidelines.

Based on these instruments and with the elaboration of a more restrictive policy for the use of water resources, the City Hall could discourage the installation of new projects that are intensive users of groundwater, such as large irrigators and industries of beverage, food, textile, etc.; and, on the other hand, encourage the installation of activities that consume little water, such as clothing, textiles without dyeing, mechanics without metallurgy etc. Even large users that consume surface water of lower quality could also be encouraged to settle in the Jacaré-Guaçu River region, where water availability is sufficient, as previously mentioned.

The CBH-TJ and the City Hall, together with the State Department of Agriculture, should encourage rural activities using less water for irrigation as to their installation 
outside the recharge areas of the stressed underground aquifers.

The DAEE, CBH-TJ, DAAE and Universities in the region should prioritize the conduct of surveys, studies and research in order to review and deepen/ detail specific technical issues, such as: assessing the availability of exploitable reserves of groundwater in the Jacaré-Guaçu Basin and in the critical municipalities; carrying out hydrogeological studies of the behavior/ runoff of the aquifers that supply the deep wells of these municipalities; evaluation of the influence of groundwater exploration in the rural area on the exploitation in the urban area of Araraquara and vice versa, as well as the influence between wells located in that urban area.

It is suggested that a special committee should be formed to monitor and even participate in the management of groundwater in critical municipalities, with representatives of the main key actors involved in that issue, who would report to the CBH-TJ and the respective Municipal Authority.

It is reinforced that public policies aimed at the elaboration of criteria for the use of water resources in the municipalities should take into account the potential for conflicts, both in the cases of surface water and, mainly of groundwater, which is not yet covered by sufficiently severe regulatory regime, proportional to the importance of this resource for the population and community in general.

Finally, it is hoped that this study may serve as an incentive for other similar studies, either in the Tietê-Jacaré Basin or in municipalities in other basins. The research findings and the suggested methodology for assessing the potential risk of water conflicts for groundwater, based on the analysis between the supply and demand for the use of these resources in areas of different conditions of economic and social development, suggest possibilities as to the reduction of conflicts, planning and more rational control for the use of groundwater, which is still poorly regulated under these aspects.

\section{References}

ABRÃO JUNIOR, F.; AGUIAR, P. R. Custos ambientais internos, um estudo aplicado ao Aeroporto Santos Dumont. In: CONGRESSO NACIONAL DE PESQUISA EM TRANSPORTE DA ANPET, XXIX, 2015, Ouro Preto. Anais...Ouro Preto, MG: ANPET, 2015. p. 2532-2541.

AMORIM, A. L.; RIBEIRO, M. M. R.; BRAGA, C. F. C. Conflitos em bacias hidrográficas compartilhadas: o caso da bacia do rio Piranhas-Açu/PB-RN. Revista Brasileira de Recursos Hídricos, Porto Alegre, v. 21, n.1, p. 36-45, 2016.

ANA - Agência Nacional de Águas. Conjuntura dos recursos hídricos no Brasil: informe 2014. Brasília: ANA, 2015. Disponível em: < http://www3.snirh.gov.br/portal/snirh/centrais-de-conteudos/ conjuntura-dos-recursos-hidricos/informes2014.pdf>. Acesso em: 18 out. 2017.

ARARAQUARA. Prefeitura Municipal. Lei Complementar No 850, de 11 de fevereiro de 2014. Estabelece a revisão do Plano Diretor de Desenvolvimento e Política Ambiental de Araraquara. Disponível em: <http://www3.araraquara.sp.gov.br/Pagina/Default.aspx?IDPagina=3973>. 
Acesso em: 22 jun. 2018.

ARARAQUARA. Prefeitura Municipal; WALM. Engenharia e Tecnologia Ambiental. Plano municipal de saneamento básico. Araraquara: DAAE, 2014. Disponível em: < https://daaeararaquara.com.br/images/PMSB_araraquara-compactado.pdf >. Acesso em: 09 mar. 2020.

BORBA, N. Z.; BAYER, D. A. A água como bem jurídico econômico. Temiminós Revista Científica, Rio de Janeiro, v. 5, n. 1, p. 96-110, 2015.

BRASIL. Lei no 9.433, de 8 de janeiro de 1997. Institui a Política Nacional de Recursos Hídricos, cria o Sistema Nacional de Gerenciamento de Recursos Hídricos, regulamenta o Inciso XIX do Art. 21 da Constituição Federal, e altera o Art. 1ํ da Lei no 8.001, de 13 de março de 1990. Diário Oficial da União, Brasília, DF, 08 jan. 1997. p. 470.

BRITO, F. B. O conflito pelo uso da água do açude Epitácio Pessoa - PB. Dissertação (Mestrado em Geografia) - Centro de Ciências Exatas e da Natureza, Universidade Federal da Paraíba, João Pessoa, 2008.

CAMPANHA, L. J; LORENZO H. C. A implementação da lei do microempreendedor individual MEI (128/2008) no município de Araraquara-SP. Revista Brasileira Multidisciplinar, Araraquara, v. 20, n. 1, p. 71-86, 2017.

CAMPOS, V. N. DE O.; FRACALANZA, A. P. Governança das águas no Brasil: conflitos pela apropriação da água e a busca da integração como consenso. Ambiente $\mathbb{\&}$ Sociedade, São Paulo, v. 13, n. 2, p. 365-382, 2010.

CANUTO, A.; LUZ, C. R. S.; ANDRADE, T. V. P. Conflitos no campo Brasil 2015. Goiânia: CPT Nacional, 2016. Disponível em: <https:/www.cptnacional.org.br/ component/ jdownloads/?task $=$ download.send\&id $=14019 \&$ catid $=0 \& \mathrm{~m}=0 \&$ Itemid $=2>$. Acesso em: 25 nov. 2018.

CARNEIRO, E. J.; ASSIS, M. F. DA C. Conflitos ambientais em Minas Gerais: exploração da água na microrregião de São Lourenço. Estudios Sociales, Hermosillo, México, v. 21, n. 41, p. 11-29, 2013.

CBH-TJ - Comitê da Bacia Hidrográfica do Tietê-Jacaré. Relatórios de situação dos recursos hídricos: 2015 - 2018. Araraquara: CBH-TJ, 2018. Disponível em: < http:/www.sigrh.sp.gov.br/ cbhtj/documentos $>$. Acesso em: 18 jun. 2018.

CETESB - Companhia Ambiental do Estado de São Paulo. Qualidade das águas subterrâneas no Estado de São Paulo: 2016 - 2018. São Paulo: CETESB, 2019a. Disponível em: < https:// cetesb.sp.gov.br/aguas-subterraneas/publicacoes-e-relatorios/>. Acesso em: 07 mai. 2018.

CETESB - Companhia Ambiental do Estado de São Paulo. Relatório de qualidade das águas interiores do Estado de São Paulo: 2018. São Paulo: CETESB, 2019b. Disponível em: < https:// cetesb.sp.gov.br/aguas-interiores/publicacoes-e-relatorios/>. Acesso em: 03 jun. 2018.

CHAVES, H. M. L.; ALBUQUERQUE, A.C.L.; MATTOS, I. Impactos da variabilidade e das 
mudanças climáticas sobre a recarga da água subterrânea em bacias com dados escassos. In: CONGRESSO BRASILEIRO DE ÁGUAS SUBTERRÂNEAS, XVI, 2010, São Luís. Anais... São Paulo, ABAS, 2010, p.1-17.

CORREIA, C. D. A. et al. Resolução de conflitos em bacias compartilhadas: análise da ferramenta construção de consenso do Global Water Partnership (GWP) aplicada à bacia do rio Poti. Revista Brasileira de Recursos Hídricos, Porto Alegre, v. 17, n. 4, p. 183-195, 2012.

COSTA, L. F. et al. Crise hídrica na Bacia do Rio Paraíba do Sul: enfrentando a pior estiagem dos últimos 85 anos. Revista Ineana, Rio de Janeiro, v. 3, n. 1, p. 26-47, 2015.

CPT - Comissão Pastoral da Terra. Conflitos pela água. Goiânia: CPT, 2019. Disponível em: < https://www.cptnacional.org.br/publicacao/category/6-conflitos-pela-agua>. Acesso em: 20 abr. 2019.

DENICOLA, E. et al. Climate change and water scarcity: the case of Saudi Arabia. Annals of Global Health, London, v. 81, n. 3, p. 342-353, 2015.

DI MAURO, C. A. Conflitos pelo uso da água. Caderno Prudentino de Geografia, Presidente Prudente, v. especial, n.36, p. 81-105, 2014.

FEARNSIDE, PHILIP M. Represas hidroeléctricas en la Amazonía brasileña: impactos ambientales y sociales. Revista de Estudios Brasileños, Salamanca, v. 6, n. 11, p. 123-138, 2019.

GETIRANA, A. C. V. Análise de soluções de conflitos pelo uso da água no setor agrícola através de técnicas de programação linear. Dissertação (Mestrado em Engenharia Civil) - COPPE, Coordenação dos Programas de Pós-Graduação de Engenharia, Universidade Federal do Rio de Janeiro, Rio de Janeiro, 2005.

HESPANHOL, I. Potencial de reuso de água no Brasil: agricultura, indústria, municípios, recarga de aquíferos. Revista Brasileira de Recursos Hídricos, Porto Alegre, v.7, n.4, p. 75-95, 2002.

HOMER-DIXON, T. F. Environmental scarcities and violent conflict evidence from cases. International Security, Cambridge, MA, v. 19, n. 1, p. 5-40, 1994.

IBGE - Instituto Brasileiro de Geografia e Estatística. População: censo demográfico; estimativas de população. Rio de Janeiro: IBGE, 2019. Disponível em: < https://www.ibge.gov.br/estatisticas/ sociais/populacao.html>. Acesso em: 17 mar. 2019.

JACOBI, P. R.; CIBIM, J.; LEÃO, R. S. Crise hídrica na macrometrópole paulista e respostas da sociedade civil. Estudos Avançados, São Paulo, v. 29, n. 84, p. 27-42, 2015.

LANNA, A. E. A economia dos recursos hídricos: os desafios da alocação eficiente de um recurso (cada vez mais) escasso. Estudos Avançados, São Paulo, v. 22, n. 63, p. 113-130, 2008.

LANNA, A. E. Introdução à gestão das águas no Brasil. Porto Alegre: AlfaSigma, 2001. Disponível em: https://www.researchgate.net/publication/309490930_Introducao_a_Gestao_das_Aguas_ no_Brasil>. Acesso em: 09 mar. 2020. 
MACHADO, P. B. Conflitos pelo uso da água: papel mediador do Comitê da Bacia Hidrográfica do Lago de Palmas. Dissertação (Mestrado em Prestação Jurisdicional e Direitos Humanos) PPGPJDH, Universidade Federal do Tocantins, Palmas, 2019.

MALHEIROS, T. F; PROTA, M. G.; RINCON, M. A. P. Participação comunitária e implementação dos instrumentos de gestão da água em bacias hidrográficas. Revista Ambiente e Água, Taubaté, v. 18, n. 1, p. 98-118, 2013.

MEKONNEN, M. M.; HOEKSTRA, A. Y. Four billion people facing severe water scarcity. Science Advances, Washington, DC, v. 2, n. 2, p. 01-06, 2016.

MOREIRA, M. C. et al. Índices para identificação de conflitos pelo uso da água: proposição metodológica e estudo de caso. Revista Brasileira de Recursos Hídricos, Porto Alegre, v. 17, n. 3, p. 7-15, 2012.

PACIFIC INSTITUTE. The world's water: water conflict. Oakland, CA: Pacific Institute, 2019. Disponível em: < https://www.worldwater.org/water-conflict/>. Acesso em: 01 mar. 2019.

PEEK, K. Where will the world's water conflicts erupt? A heatmap of war over water. Harlan, IA: Popular Science, 2014. Disponível em: < https://www.popsci.com/article/science/where-will-worlds-water-conflicts-erupt-infographic >. Acesso em: 30 mai. 2018.

PEINADO, J.; GRAEML, A. R. Administração da produção: operações industriais e de serviços. Curitiba: UNICENP, 2007.

PETRELLA, R. O manifesto da água: argumentos para um contrato mundial. 2. ed. Petrópolis: Vozes, 2004.

PINHEIRO, M. I. T.; CAMPOS, J. N. B.; STUDART, T. M. D. C. Conflitos por águas e alocação negociada: o caso do vale dos Carás no Ceará. Revista de Administração Pública, Rio de Janeiro, v. 45, n. 6, p. 1655-1672, 2011.

REBOUÇAS, A. C. Proteção dos recursos hídricos. Revista de Direito Ambiental, São Paulo, v. 8, n. 32, p. 33-67, 2003.

ROCHA, C. O impacto ambiental das hidrelétricas da Amazônia. São Paulo: Nexo Jornal, 2019. Disponível em: <https://www.nexojornal.com.br/expresso/2019/09/23/O-impacto-ambiental-das-hidrel\%C3\%A9tricas-da-Amaz\%C3\%B4nia>. Acesso em: 11 jun. 2019.

SALVADOR, N. N. B.; FIGUEIREDO, R. A.; MACHADO, A. M. R. The use of the ABC Method to prioritize the control of laboratory chemical waste in a university campus. In: SIMPÓSIO ÍTALO-BRASILEIRO DE ENGENHARIA SANITÁRIA E AMBIENTAL, 9, 2008, Florença. Anais... Rio de Janeiro: ABES/SIDISA, p.1-20, 2008.

SÃO PAULO (Estado). Decreto no 59.113, de 23 de abril de 2013. Estabelece novos padrões de qualidade do ar e dá providências correlatas. Diário Oficial do Estado de São Paulo. São Paulo, 24 abr. 2013. p. 1.

SDC - Swiss Agency for Development and Cooperation. Water as an asset for peace: atlas 
of risks and opportunities. Bern: SDC, 2017. Disponível em: < https:/www.eda.admin.ch/dam/ deza/en/documents/themen/wasser/Water-Atlas_EN.pdf >. Acesso em: 11 jan. 2021.

TUNDISI, J. G.; MATSUMURA-TUNDISI, T. A água. 2. ed. São Paulo: Publifolha, 2009.

VARGAS, G. M. Conflitos sociais e socioambientais: propostas de um marco teórico e metodológico. Sociedade $\mathbb{\&}$ Natureza, Uberlândia, v. 19, n. 2, p. 191-203, 2007.

VILLAR, P. C. As águas subterrâneas e o direito à água em um contexto de crise. Ambiente $\mathbb{\&}$ Sociedade, São Paulo, v.19, n.1, p. 83-102, 2016.

YIN, R. K. Estudo de caso: planejamento e métodos. Porto Alegre: Bookman, 5. ed., 2015. 
Larissa Camerlengo Dias Gomes

$\checkmark$ larissacdgomes@uniara.edu.br

ORCiD: https://orcid.org/0000-0001-8295-8818
Submitted on: 03/06/2019

Accepted on: 08/03/2021

2021;24e:01003

\section{Nemésio Neves Batista Salvador}

$\checkmark$ nemesio.salvador@gmail.com

ORCiD: https://orcid.org/0000-0002-4158-1951

\section{Helena Carvalho de Lorenzo}

$\checkmark$ helenadelorenzo@gmail.com

ORCiD: https://orcid.org/0000-0002-7744-0157

How to cite: GOMES, L.C.D; SALVADOR, N.N.B; DE LORENZO, H.C. Conflitos pelo uso dos recursos hídricos e o caso de Araraquara-SP. Ambiente $\mathbb{\&}$ Sociedade. São Paulo, v. 24, p. 1-20, 2021. 


\title{
CONFLITOS PELO USO DOS RECURSOS HÍDRICOS E O CASO DE ARARAQUARA-SP
}

\author{
Larissa Camerlengo Dias Gomes \\ Nemésio Neves Batista Salvador \\ Helena Carvalho De Lorenzo
}

São Paulo. Vol. 24, 2021

Artigo Original
Resumo: Neste trabalho são apresentados conflitos hídricos no Brasil, suas causas e efeitos e o caso de conflitos relativos à oferta e demanda de água subterrânea no município de Araraquara-SP, Brasil. Nele a situação é classificada como crítica pelo Comitê da Bacia Hidrográfica Tietê-Jacaré (CBH-TJ), ao qual pertence. Foram identificados os principais fatores de conflito em Araraquara e os atores-chave envolvidos. Determinou-se as demandas dos usuários de água subterrânea e foram identificados, por meio do Método $\mathrm{ABC}$, os responsáveis pela maior parte da demanda total, os quais, mesmo em pequeno número, são os principais potenciais causadores de conflitos envolvendo o abastecimento público e o privado. São discutidas também políticas públicas relacionadas à gestão dos recursos hídricos e à ocorrência de conflitos, propondo-se medidas para a sua atenuação. Tais medidas devem ser implementadas pelos atores-chave e principais usuários de água subterrânea envolvidos.

Palavras-chave: Recursos hídricos; águas subterrâneas; conflitos.

Como citar: GOMES, L.C.D; SALVADOR, N.N.B; DE LORENZO, H.C. Conflitos pelo uso dos recursos hídricos e o caso de Araraquara-SP. Ambiente \& Sociedade. São Paulo, v. 24, p. 1-20, 2021.

DOI: http://dx.doi.org/10.1590/1809-4422asoc20190100r3vu2021L3AO 


\title{
CONFLICTOS POR EL USO DE LOS RECURSOS HIDRICOS Y EL CASO DE ARARAQUARA-SP
}

\author{
Larissa Camerlengo Dias Gomes \\ Nemésio Neves Batista Salvador \\ Helena Carvalho De Lorenzo
}

São Paulo. Vol. 24, 2021

Resumen: En este trabajo se presentan conflictos hídricos en Brasil, sus Artículo original causas y efectos y el caso de conflictos relacionados con la oferta y demanda de aguas subterráneas en la municipalidad de Araraquara-SP, Brasil. En ella, la situación se clasifica como crítica por el Comité de la Cuenca Hidrográfica Tietê-Jacaré, al que pertenece. Se identificaron los principales factores de conflicto en Araraquara y los actores clave involucrados. Se ha determinado las demandas de los usuarios de aguas subterráneas y se identificaron, por el Método $\mathrm{ABC}$, los responsables por la mayor parte de la demanda total, que mismo en pequeño número, son los principales potenciales causadores de conflictos en el abastecimiento público y privado. Políticas públicas relacionadas con la gestión de los recursos hídricos fueron analizadas. Para la atenuación de los conflictos, fueron propuestas medidas a ser implementadas por actores clave y principales usuarios de aguas subterráneas involucrados.

Palabras-clave: Recursos hídricos, agua subterránea, conflictos.

Como citar: GOMES, L.C.D; SALVADOR, N.N.B; DE LORENZO, H.C. Conflictos por el uso de los recursos hídricos y el caso de Araraquara-SP. Ambiente $\&$ Sociedade. São Paulo, v. 24, p. 1-20, 2021.

DOI: http://dx.doi.org/10.1590/1809-4422asoc20190100r3vu2021L3AO 